\title{
PHYTOCHEMICAL CONSTITUENTS OF THE ROOT OF BERBERIS MICROPHYLLA
}

\author{
MARÍA CRISTINA FURRIANCA ${ }^{1}$, MARYSOL ALVEAR² ${ }^{2}$ TOMÁS ZAMBRANO³ , VÍCTOR FAJARDO4 ${ }^{4}$ LUIS A SALAZAR $^{3 *}$ \\ ${ }^{1}$ Department of Nursing, Universidad de Magallanes, Chile. ${ }^{2}$ Department of Chemical Sciences and Natural Resources, Universidad de La \\ Frontera, Temuco, Chile. ${ }^{3}$ Department of Basic Sciences, Center of Molecular Biology and Pharmacogenetics, Scientific and Technological \\ Bioresource Nucleus, Universidad de La Frontera, Temuco, Chile. ${ }^{4}$ Department of Science and Natural Resources, Universidad de \\ Magallanes, Punta Arenas, Chile. Email: luis.salazar@ufrontera.cl
}

Received: 16 February 2017, Revised and Accepted: 20 March 2017

\section{ABSTRACT}

Objective: To objective of this work was to perform phytochemical qualitative and quantitative analyzes of the main secondary metabolites in the root of Berberis microphylla.

Methods: The extracts of B. microphylla root were tested through phytochemical screening and the quantification of the most important constituents was carried out using spectrophotometric and gravimetric techniques.

Results: Phytochemical screening of both extracts showed the presence of alkaloids, flavonoids, glycosides, cardiac glycosides, saponins, terpenes, and tannins, which are pharmacologically important. Quantification of the major phytochemicals groups showed that the ethanolic extract contains $3.9 \%$ alkaloids, $0.46 \%$ flavonoids, $9.53 \%$ tannins, and $3.60 \%$ saponins. Similarly, the methanolic extract contains $6.61 \%$ alkaloids, $0.41 \%$ flavonoids, $7.40 \%$ tannins, and $1.43 \%$ saponins.

Conclusion: This is the first time that the presence of tannins, flavonoids, and saponins in this plant has been reported. The medicinal properties of the root of $B$. microphylla may exist due to the presence secondary metabolites.

Keywords: Calafate, Berberis microphylla, Phytochemical constituents, Secondary metabolites, Patagonian species.

(C) 2017 The Authors. Published by Innovare Academic Sciences Pvt Ltd. This is an open access article under the CC BY license (http://creativecommons. org/licenses/by/4. 0/) DOI: http://dx.doi.org/10.22159/ajpcr.2017.v10i6.17803

\section{INTRODUCTION}

There are about 500 species of Berberis worldwide, located mainly in Eurasia with approximately 300 species and 200 species in South America [1]. In Southern Chile and Argentina, from the 60 species previously reported in 1961 [2], currently, 20 species are recognized [3]. This important reduction is explained by several species, such Berberis heterophylla and Berberis buxifolia, being grouped into one species, Berberis microphylla [4]. Berberis species are deciduous or evergreen shrubs with a height of up to 5 meters tall and thorny stems, which are native to temperate and subtropical regions of Europe, Africa, North and South America [5]. At present, a large number of species of Berberis have been reported with pharmacological and clinical use [6]. In homeopathy and ethnic medicine, these species have been used as medicine for their anti-inflammatory [7], antibacterial, antihypertensive, anticancer, antiarrhythmic [8], hypoglycemic [8,9], and hepatoprotective [10-12] properties. The major phytochemical studies have been conducted on Asian species, such as Berberis jaeschkeana, Berberis asiatica, Berberis aristata, and Berberis lyceum. These species showed a relatively high content of tannins, saponins, alkaloids, flavonoids, steroids, phenolic compounds, and carbohydrates [13-15].

In the Chilean-Argentina Patagonia, the Berberis genus is represented by 16 species of native shrubs [16], among which B. microphylla-whose common name is caulk - stands out as a symbol of Patagonia due to its widespread abundance in the region [17]. B. microphylla has also been medicinally used by the native peoples of Patagonia (Aónikenk, Selk'nam, Kawésqar) for its astringent, antipyretic, analgesic, antibacterial, and antiviral properties [18].

Although several articles on B. microphylla have reported the diversity of alkaloid compounds [19,20], there are currently no studies showing the presence of other secondary metabolites in this plant. For this reason, our research is important because it reports for the first time the presence of the main secondary metabolites that have been described with biological activity. Therefore, the objective of this work was to perform phytochemical qualitative and quantitative analyzes of the main secondary metabolites in the root of B. microphylla.

\section{METHODS}

\section{Sample collection}

Roots of B. microphylla were collected in the settlement of Bahía Mansa ( $53^{\circ} 36^{\prime} 39,38^{\prime \prime} \mathrm{S}$ and $70^{\circ} 55^{\prime} 50,56^{\prime \prime} \mathrm{O}$ ), about $54 \mathrm{~km}$ South of the city of Punta Arenas, Chile. The plants of B. microphylla were collected, and taxonomic authentication was carried out by Dr. Juan Marcos Henríquez, botanist, and taxonomist at the Institute of Patagonia, Universidad de Magallanes, Chile (Voucher No: 012837).

Methanolic and ethanolic extracts preparation of $B$. microphylla root We prepared extracts of the root of B. microphylla in ethanol and methanol. For this purpose, $100 \mathrm{~g}$ of root was dried, ground and extracted with $1000 \mathrm{ml}$ of alcohol (ethanol or methanol) for $72 \mathrm{hrs}$ at room temperature. Then, the extract was filtered and concentrated in a rotary evaporator at $40^{\circ} \mathrm{C}$. Finally, the extract was lyophilized and stored at $4^{\circ} \mathrm{C}$ until use.

Qualitative phytochemical analysis

We carried out qualitative assays on both ethanolic and methanolic extracts to identify the presence of secondary metabolites, such as alkaloids, flavonoids, glycosides, cardiac glycosides, saponins, resins, phenols, tannins, triterpenes, steroids, catechins, amines, and anthocyanins based on a protocol previously described [21].

Quantitative phytochemical analysis

We submitted both extracts to quantitative biochemical testing to determine the main secondary metabolites with described medicinal activity, such as alkaloids [22,23], flavonoids [24], saponins [25], and tannins [26]. 
Table 1: Phytochemical screening in alcoholic extracts of B. microphylla root

\begin{tabular}{|c|c|c|}
\hline Constituents & Ethanol extract & Methanol extract \\
\hline Alkaloids & + & + \\
\hline Flavonoids & + & + \\
\hline Glycosides & + & + \\
\hline Cardiac glycosides & + & + \\
\hline Saponins & + & + \\
\hline Resins & - & - \\
\hline Phenols & + & + \\
\hline Tannins & + & + \\
\hline Terpenes & + & + \\
\hline Triterpenes & - & - \\
\hline Quinones & + & + \\
\hline Catechins & - & - \\
\hline Amines & - & - \\
\hline Anthocyanins & - & - \\
\hline
\end{tabular}

-: Absence, +: Presence, B. microphylla: Berberis microphylla

Table 2: Phytochemical composition of B. microphylla root extract

\begin{tabular}{|c|c|c|c|c|c|c|c|}
\hline \multirow[t]{2}{*}{ Extract } & \multicolumn{2}{|l|}{ Alkaloids } & \multicolumn{2}{|l|}{ Flavonoids } & \multicolumn{2}{|l|}{ Tannins } & \multirow[t]{2}{*}{ Saponins \% } \\
\hline & $\begin{array}{l}\text { mg equivalents } \\
\text { berberine/g dry } \\
\text { matter }\end{array}$ & $\%$ & $\begin{array}{l}\text { mg equivalents } \\
\text { quercetin/g dry } \\
\text { matter }\end{array}$ & $\%$ & $\begin{array}{l}\text { mg equivalents } \\
\text { tannic acid/g dry } \\
\text { matter }\end{array}$ & $\%$ & \\
\hline Ethanol & $1.16 \pm 0.05$ & $3.90 \pm 0.15$ & $0.13 \pm 0.11$ & $0.46 \pm 0.37$ & $2.85 \pm 0.12$ & $9.53 \pm 0.41$ & $3.60 \pm 0.53$ \\
\hline Methanol & $3.64 \pm 0.17$ & $6.61 \pm 0.30^{*}$ & $0.22 \pm 0.21$ & $0.41 \pm 0.37$ & $4.09 \pm 0.36$ & $7.40 \pm 0.65$ & $1.43 \pm 0.27$ \\
\hline
\end{tabular}

Values expressed as mean \pm SD and correspond to mg equivalent $\mathrm{g}^{-1}$ of dry weight and percentage. *Significant versus percentage of ethanol extract ( $\mathrm{p}<0.05$ ),

SD: Standard deviation, B. microphylla: Berberis microphylla

\section{Data analysis}

Statistical analysis was completed using the R software version 3.2.2 GNU General Public License (GNU). All analyses were performed in triplicate. Continuous variables are presented as mean \pm SD. The comparison between both extracts was assessed by Student's t-test for independent samples. Two-tailed $\mathrm{p}<0.05$ was considered statistically significant.

\section{RESULTS AND DISCUSSION}

Qualitative phytochemical analysis

Different reports highlight $B$. microphylla as an important source of alkaloid compounds [16,17]. However, there is little background information on other secondary metabolites of this plant. Thus, as far as we know, this work constitutes the first report describing the presence of other phytochemical constituents in the root of $B$. microphylla. Results of the qualitative phytochemical analysis are shown in Table 1. It is important to note that our results are consistent with those described for B. asiatica [15], B. aristata [14], B. tinctoria [27], and B. lyceum [28].

\section{Quantitative analysis}

We quantified four phytochemicals groups known to be important in natural medicine [29]. Interestingly, Tiwari et al. underlined the role that saponins and tannins perform in the control and management of hyperglycemia [30], which seems to be similar to alkaloids [28].

The total alkaloids contents were reported as mg equivalents of berberine. Their percentage in the methanolic extract was significantly higher compared to the percentage in the ethanolic extract. This may be due to the type of polarity of the solvent used. In the literature, there are various reports regarding the total alkaloid content of dry roots. For instance, B. thunbergii (3.47\%) and B. vulgaris (2.22\%) [31] show lower percentages than those found in B. microphylla, which may be due to the content of berberine, which is the main alkaloid, varying considerably with altitude and soil conditions for the root [31-33]. Total flavonoids were reported as mg equivalents of quercetin. No significant difference was found between the two extracts tested. In the literature, values of close to $2.8 \%$ of flavonoids in B. aristata are reported [34], a value higher than that found in B. microphylla. Total tannins contents were reports as mg equivalents of tannic acid. The percentage of tannins is roughly similar in several species of Berberis; however, the root of $B$. microphylla contained a higher percentage of tannins than those described for B. aristata $(0.6 \%)$, B. asiatica $(1.7 \%)$, B. chitria $(0.73 \%)$, and $B$. lyceum $(0.96 \%)$ [35]. Moreover, the percentage of saponins is greater in B. microphylla than in B. vulgaris (0.3\%) [36]. No significant differences were found in both extracts tested for these phytochemical groups. The phytochemical composition of both extracts was expressed in $\mathrm{mg} \mathrm{g}^{-1}$ of dry matter of the sample $( \pm \mathrm{SD})$ and percentage $( \pm \mathrm{SD})$, and the results are shown in Table 2.

\section{CONCLUSION}

The phytochemical study showed that the root extracts of B. microphylla contain important bioactive secondary metabolites, without qualitative differences between the ethanolic and methanolic extract of the plant. This would be the first time to report the presence of tannins, flavonoids, and saponins present in the root of B. microphylla. Quantitatively, the tannins would be the major group for both extracts tested. Therefore, their presence would support the traditional use of the plant in the treatment of various diseases. We are conducting further studies of the isolation of active components from the root of B. microphylla with cell lines to validate the medicinal use of this plant.

\section{ACKNOWLEDGMENTS}

The authors would like to thank Advanced Human Capital Formation Program, CONICYT-CHILE for their financial support of María Cristina Furrianca Llaneza during her National Doctorate fellow ( $\left.{ }^{\circ} 24121475\right)$.

\section{REFERENCES}

1. Bottini MC, De Bustos A, Sanso AM, Jouve N, Poggio L. Relationships in Patagonian species of Berberis (Berberidaceae) based on the characterization of rDNA internal transcribed spacer sequences. Bot J Linn Soc 2007;153(3):321-8.

2. Ahrendt LW. Berberis and Mahonia. J Linn Soc London Bot 1961;57(369): $1-410$

3. Landrum LR. Revision of Berberis (Berberidaceae) in Chile and adjacent Southern Argentina. Ann Missouri Bot Gard 1999;86(4):793-834. Available from: http://www.biostor.org/reference/13047. 
4. Varas B, Castro MH, Rodriguez R, von Baer D, Mardones C, Hinrichsen P. Identification and characterization of microsatellites from calafate (Berberis microphylla, Berberidaceae). Appl Plant Sci 2013;1. pii: apps. 1200003

5. Sodagar N, Bahrami AR, Memariani F, Ejtehadi H, Vaezi J, Khosravi AR. Biosystematic study of the genus Berberis L. (Berberidaceae) in Khorassan, NE Iran. Plant Syst Evol 2012;298(1):193-203.

6. Mazumder PM, Das S, Das S, Das MK. Phyto-pharmacology of Berberis aristata DC: A Review. J Drug Deliv Ther 2011;1(2). Available from: http://www.jddtonline.info/index.php/jddt/article/view/34/25.

7. Singh V, Gunjan, Katiyar D. Anti-inflammatory activity of alcoholic and aqueous heartwood extracts of Berberis aristata DC. Asian J Pharm Clin Res 2014;7 Suppl 1:210-2.

8. Mokhber-Dezfuli N, Saeidnia S, Gohari AR, KurepazMahmoodabadi M. Phytochemistry and pharmacology of Berberis Species. Pharmacogn Rev 2014;8(15):8-15.

9. Ahamad J, Mir S, Naquvi K. Hypoglycemic activity of aqueous extract of Berberis aristata stems bark in stz-induced rats. Int J Pharm Pharm Sci 2012;4(2):473-4.

10. Upwar N, Patel R, Waseem N, Kumar Mahobia N. Hypoglycemic effect of methanolic extract of Berberis aristata DC stem on normal and streptozotocin induced diabetic rats. Int $\mathrm{J}$ Pharm Pharm Sci 2011;3(1):222-4

11. Unkeshwar P, Nasiruddin M, Fayazuddin M, Khan R, Khan A, Tajuddin. Evaluation of hepatoprotective activity of Berberis aristata against carbon tetrachloride induced hepatotoxicity in rats. Int J Pharm Pharm Sci 2013;5 Suppl 4:107-10. Available from: http://www.amu. ac.in/dshowfacultydata.jsp?did $=121 \&$ eid $=10055150$.

12. Dehar N, Walia R, Verma RB, Pandey P. Hepatoprotective activity of Berberis aristata root extract against chemical induced acute hepatotoxicity in rats. Asian J Pharm Clin Res 2013;6 Suppl 5:53-6.

13. Alamzeb M, Khan MR, Ali S, Shah SQ, Rashid MU. Antimicrobial properties of extracts and compounds isolated from Berberis jaeschkeana. Bangladesh J Pharmacol 2013;8(2):107-9.

14. Mittal M, Juyal V, Singh A. Phytochemical, antidiabetic, and cytoprotective properties of Berberis aristata DC. root extracts. Pharm Crop 2012;3:64-8.

15. Patni S, Sah AN, Meena H, Pandey HK. Physico-chemical, phytochemical and elemental analysis of stem bark and roots of Berberis asiatica. Adv Appl Sci Res 2012;3(6):3624-8.

16. Arena ME, Curvetto N. Berberis buxifolia fruiting: Kinetic growth behavior and evolution of chemical properties during the fruiting period and different growing seasons. Sci Hortic (Amsterdam) 2008;118(2):120-7. Available from: http://www.linkinghub.elsevier. com/retrieve/pii/S0304423808002069. [Last cited on 2014 Sep 5].

17. Fajardo V, Urzúa A, Torres R, Cassels B. Secondary metabolites from Berberis buxifolia. Rev Latinoamer Quím 1979;10:131-4.

18. Domínguez E. Flora of ethnobotanical interest used by the indigenous: Aónikenk, Selk'nam, Kawésqar, Yagan and Haush in the Southernmost Patagonia 2010;26(2):19-29.

19. Echeverria J, Niemeyer HM. Alkaloids from the native flora of Chile: A review. Bol Latinoam Caribe Plant Med Aromat 2012;11(4):291-305.

20. Manosalva L, Mutis A, Diaz J, Urzua A, Fajardo V, Quiroz A. Identification of isoquinoline alkaloids from Berberis microphylla by HPLC ESI-MS/MS. Bol Latinoam Caribe Plant Med Aromat 2014;13:323-34
21. Gowri SS, Vasantha K. Phytochemical screening and antibacterial activity of Syzygium cumini (L.) (Myrtaceae) leaves extracts. Int J Pharm Tech Res 2010;2(2):1569-73.

22. Patel RK, Patel JB, Trivedi PD. Spectrophotometric method for the estimation of total alkaloids in the Tinospora cordifolia $\mathrm{M}$. and its herbal formulations. Int J Pharm Pharm Sci 2015 20;7(10):249-51. Available from: http://www.innovareacademics.in/journals/index.php/ ijpps/article/view/7622/6129.

23. Shamsa F, MonsefH, Ghamooshi R, Verdian-rizi M. Spectrophotometric determination of total alkaloids in some Iranian medicinal plants. Thai J Pharm Sci 2008;32:17-20.

24. Naskar S, Mazumder UK, Pramanik G, Bala A, Haldar PK, Islam A, et al. Comparative in vitro antioxidant activity of different parts of Cocos nucifera (Linn.) on reactive oxygen and nitrogen species. Int $\mathrm{J}$ Pharm Pharm Sci 2011;3 Suppl 3:104-7.

25. Gulfraz M, Asad M, Qaddir G, Mehmood S, Shaukat S, Parveen Z. Phytochemical constituents of Berberis lycium royle and Justicia adhatoda. J Chem Soc Pak 2008:30:453-7.

26. Attarde D, Patil M, Chaudhari B, Pal S. Estimation of tannin content in some marketed Harde churna (Terminalia chebula Retz. FamilyCombretaceae). Int J Pharm Technol 2010;2(3):750-6.

27. Doss A. Preliminary phytochemical screening of some Indian medicinal plants. Anc Sci Life 2009;29(2):12-6.

28. Gulfraz M, Mehmood S, Ahmad A, Fatima N, Praveen Z, Williamson EM. Comparison of the antidiabetic activity of Berberis lyceum root extract and berberine in alloxan-induced diabetic rats. Phyther Res 2008;22(9):1208-12.

29. Otshudi AL, Vercruysse A, Foriers A. Contribution to the ethnobotanical, phytochemical and pharmacological studies of traditionally used medicinal plants in the treatment of dysentery and diarrhoea in Lomela area, Democratic Republic of Congo (DRC). J Ethnopharmacol 2000;71(3):411-23. Available from: http:/www.sciencedirect.com/ science/article/pii/S0378874100001677.

30. Tiwari AK, Rao JM. Diabetes mellitus and multiple therapeutic approaches of phytochemicals: Present status and future prospects. Curr Sci 2002;83(1):30-8.

31. Villinski J, Dumas E, Chai HB, Pezzuto J, Angerhofer C, Gafner S. Antibacterial activity and alkaloid content of Berberis thunbergii, Berberis vulgaris and Hydrastis canadensis. Pharm Biol 2003;41(8):551-7

32. Andola HC, Gaira KS, Rawal RS, Rawat MS, Bhatt ID. Habitatdependent variations in berberine content of Berberis asiatica Roxb. ex. DC. in Kumaon, Western Himalaya. Chem Biodivers 2010;7(2):415-20.

33. Maithani A, Parcha V, Kumar D. Quantitative estimation of berberine content of Berberis asiatica from different altitude of Garhwal Himalaya. Asian J Pharm Clin Res 2014;7 Suppl 1:165-7.

34. Patel DK, Patel K, Dhanabal SP. Standardization of Berberis aristata extract through conventional and modern HPTLC techniques. Asian Pac J Trop Dis 2012;2:S136-40.

35. Srivastava S, Rawat AK. Quality evaluation of ayurvedic crude drug daruharidra, its allied species, and commercial samples from herbal drug markets of India. Evid Based Complement Alternat Med 2013;2013:472973.

36. El Sayed M, Ghareeb DA, Khalil AA, Sarhan EM. Therapeutic bioscreening of the bioactive ingredients of Berberis vulgaris. Funct Plant Sci Biotechnol 2011;13:63-8. 